\title{
Kamila Doktór-Bindas
}

Katolicki Uniwersytet Lubelski

\section{IMPLEMENTACJA PRAWA UNII EUROPEJSKIEJ WE WŁOSZECH W KONTEKŚCIE ZMIAN WPROWADZONYCH PRZEZ TRAKTAT Z LIZBONY}

\section{WPROWADZENIE}

Członkostwo w Unii Europejskiej oraz obowiązek przestrzegania prawa stanowionego przez tę organizację wymusza na państwach podejmowanie szeregu czynności mających zapewnić właściwe funkcjonowanie zasad, reguł i przepisów europejskich w warunkach wewnętrznych. Konieczność implementacji prawa unijnego jest jedną z głównych konsekwencji przynależności do struktur Unii i wypływa bezpośrednio z unormowań traktatowych - art. 291 ust. 1 Traktatu o funkcjonowaniu Unii Europejskiej stanowi: „Państwa Członkowskie przyjmują wszelkie środki prawa krajowego niezbędne do wprowadzenia w życie prawnie wiążących aktów Unii”. Zgodnie z dyspozycją tego przepisu wybór środków i metod działania, zmierzających do wdrożenia unormowań unijnych, jest pozostawiony poszczególnym krajom członkowskim. W konsekwencji tego instytucje państwowe, władze centralne, lokalne i cała administracja muszą posiadać stosowne kompetencje o charakterze implementacyjnym oraz czynnie uczestniczyć w procesach dostosowujących prawo krajowe do wymogów stawianych przez Unię. Niektóre państwa członkowskie tworzą ponadto szczególne „wdrażające” instrumenty normatywne, nierzadko reorganizując tym samym swój krajowy porządek normatywny. 
Na tym tle Włochy są bardzo interesującym badawczo państwem. Jako tzw. „stary” kraj członkowski (bo przecież jeden z założycieli Wspólnot) wykształciły już wieloletnią praktykę stosowania na swym terytorium prawa unijnego, a co się z tym nierozerwalnie wiąże, także ciekawe techniki i metody jego wdrażania. Dwie kwestie, w moim odczuciu, czynią Italię szczególnie atrakcyjnym przedmiotem głębszej analizy naukowej w obszarze dostosowania prawa krajowego do unijnego. Po pierwsze, instrument tzw. ustawy wspólnotowej (legge comunitaria), za pomocą której dokonywana jest zbiorcza, coroczna implementacja przepisów europejskich do porządku wewnętrznego państwa; po drugie, udział w tych procesach regionów włoskich.

Omawiane zagadnienie implementacji prawa Unii Europejskiej we Włoszech wymaga jednak dzisiaj nieco szerszego spojrzenia na główne kwestie z nim związane. Należy bowiem mieć na uwadze, iż Traktat z Lizbony, który wszedł w życie 1 grudnia 2009 r., sprowokował w kraju wewnętrzną debatę polityczną i naukową, w wyniku której w najbliższej przyszłości muszą ulec zmianie wewnętrzne unormowania regulujące tą kwestię.

\section{KWESTIA IMPLEMENTACJI PRAWA UNII EUROPEJSKIEJ WE WLOSZECH - RYS HISTORYCZNY}

Przez bardzo wiele lat członkostwa Republiki Włoskiej we Wspólnotach Europejskich główną metodą implementacji dyrektyw wspólnotowych (a także często zaleceń wspólnotowych i do pewnego momentu nawet rozporządzeń) była metoda ustawodawstwa delegowanego. Polegała ona na tym, iż parlament włoski przekazywał stosowne uprawnienia dla rządu włoskiego w celu dokonania transpozycji do wewnętrznego systemu prawa poszczególnych dyrektyw wspólnotowych. Instytucja ustawodawstwa delegowanego jest przewidziana przez art. 76 Konstytucji i także dziś pełni doniosłą rolę w procesie transpozycji dyrektyw, jednak w pewnym okresie była ona zdecydowanie nadużywana'. Delegowanie uprawnień

${ }^{1}$ Powszechne użycie we Włoszech tego instrumentu normatywnego rozpoczęło się już od momentu wejścia w życie ustawy nr 1203 wprowadzającej Traktaty Rzymskie do krajowego systemu prawnego. Art. 4 tejże ustawy przewidywał delegowanie dla rządu włoskiego kompetencji w przedmiocie wprowadzenia w życie niektórych postanowień samych Traktatów (CELOTTO A. (2003), L'eficacia delle fonti comunitarie nell'ordinamento italiano; normativa, giurisprudenza e prassi, Torino, p. 280). Użycie ustawodawstwa delegowanego upowszechniło się znacznie w latach 60. XX w., gdy Italia musiała sprostać wymaganiom Wspólnot w związku z upływem terminu dla okresu przejściowego do utworzenia rynku wspólnego i w tym celu wprowadzić do systemu wewnętrznego szereg dyrektyw (najbardziej ewidentnymi przykładami są dwie ustawy 
rządowi przez parlament, jakkolwiek wydawało się być swego czasu idealnym remedium na skuteczną implementację prawa Wspólnot, wiązało się z dwoma głównymi problemami: po pierwsze, wzbudzało powszechnie wątpliwości co do zgodności takiego postępowania z Konstytucją. Art. 76 stanowi przecież: „Wykonywanie funkcji ustawodawczej może zostać przekazane rządowi tylko pod warunkiem określenia zasad i kierunkowych wytycznych oraz tylko na określony czas i dla określonych spraw", tymczasem delegowanie było często dokonywane na dłuższy czas, np. okres 5-letni i obejmowało wszystkie dyrektywy wspólnotowe, które w tym czasie wymagały wprowadzenia². Często także delegowano uprawnienia już po upływie terminu do implementacji dyrektywy. Po drugie, metoda ta była mało efektywna, gdyż rząd bardzo często ociągał się z wykonywaniem swych obowiązków wynikających z delegowania uprawnień, a co za tym idzie, dochodziło do ogromnych opóźnień w przedmiocie implementacji prawa wspólnotowego ${ }^{3}$. Skutek był taki, że przez wiele lat Italia zajmowała niechlubne, ostatnie miejsce w statystykach grupujących wszystkie państwa członkowskie w przedmiocie transpozycji dyrektyw, co znajdowało oddźwięk w licznych powtarzających się karach finansowych nakładanych przez Wspólnoty ${ }^{4}$. Kolejną ważną konsekwencją nadużywania ustawodawstwa delegowanego było znaczne ograniczenie roli parlamentu włoskiego w materii dostosowywania prawa krajowego do wymogów wspólnotowych, co było zresztą szeroko krytykowane nie tylko przez doktrynę, ale także przez samych członków parlamentu krajowego ${ }^{5}$.

Pierwszym wartym odnotowania punktem przełomowym w kwestii implementacji prawa Wspólnot było uchwalenie 16 kwietnia 1987 r. ustawy nr 1836,

z lat 60.: ustawa $\mathrm{nr} 871$ z 1965 r. oraz ustawa $\mathrm{nr} 740$ z 1969 r.; PITINO A. (2005), Verso una nuova legge comunitaria. Stato e regioni tra l'attuazione del Titolo $V$ e il nuovo trattato che adotta una costituzione per l'Europa, Torino, pp. 19 e.). Kolejne nadużycia ustawodawstwa delegowanego były widoczne zwłaszcza w latach 80 . XX w., gdy Włochy zmuszone były nadrobić sporo nagromadzonych przez dwie dekady opóźnień (ustawa nr 42 z 1982 r. wprowadziła do obiegu prawnego aż 97 dyrektyw wspólnotowych, w tym niektórych z datą wejścia w życie określoną aż o 20 lat wstecz!; PITINO A. (2005), Verso una nuova...).

${ }^{2}$ RONZITTI N. (1998), Wprowadzenie prawa wspólnotowego do porzqdku prawnego Włoch, in A. Maciaszczyk (a curia di), Włoskie doświadczenia w integracji europejskiej, Łódź, pp. 66-67.

${ }^{3}$ Ibidem.

${ }^{4}$ CELOTTO A. (2003), L'efficacia delle fonti comunitarie..., p. 280.

5 „One [Traktaty - przyp. K.D.B.] prowadzą do realizacji polityki będącej w ciągłej ewolucji, której wypracowanie nie może być pozostawione samym negocjacjom pomiędzy Rządami. Jest koniecznym, aby w procesie swego tworzenia, była ona wypracowywana z udziałem Parlamentów narodowych”. Cyt. za M. Giuliano, Il Parlamento italiano e la integrazione europea, [w:] „Rivista di Diritto Internazionale Privato e Processuale” 1969, n. 3, pp. 850-860.

6 „Gazzetta Ufficiale della Repubblica” nr 109, 13.05.1987, suppl. ord. 
powszechniej znanej pod nazwą ,ustawy Fabbri”. Myślą przewodnią norm legge Fabbri była dość nowatorska idea, według której powinno się maksymalnie uaktywnić Włochy na płaszczyźnie stanowienia prawa w organach Wspólnot, a zatem w tzw. fazie kreacji prawa wspólnotowego (la fase ascendente), aby uzyskać lepszą efektywność w kraju, a więc w tzw. fazie wdrażania (la fase discendente), związanej już z samą realizacją i wprowadzaniem tego systemu do porządku krajowego ${ }^{7}$. Miało temu służyć m.in. utworzenie w kraju stosownych organów zajmujących się koordynacją polityki włoskiej w tym obszarze, takich jak np. ministerstwo do spraw koordynacji polityk wspólnotowych, jak również specjalnego komitetu konsultacyjnego przy Prezydencji Rady Ministrów, mającego za zadanie badanie wpływu norm wspólnotowych na krajowy system prawa. „Ustawa Fabbri” miała także na celu uaktywnienie włoskiego parlamentu oraz regionów krajowych poprzez włączenie ich do procesu tworzenia prawa na poziomie wspólnotowym. Przyznała im tym samym możliwość kierowania do rządu swych obserwacji odnośnie projektów rozporządzeń, dyrektyw i zaleceń. Natomiast w kwestii dostosowania systemu włoskiego do prawa Wspólnot wspomniana ustawa, co szczególnie istotne, porządkowała materię normatywną, która miała być wdrażana do systemu wewnętrznego. Wskazywała jednocześnie na stosowne instrumenty prawa krajowego, za pomocą których owa adaptacja miałaby się odbyć.

Następczyni legge Fabbri, ,ustawa La Pergola”, uchwalona przez parlament włoski 9 marca 1989 r. pod nazwą: „Normy ogólne odnośnie udziału Włoch we wspólnotowym procesie prawotwórczym oraz odnośnie procedur wykonywania zobowiązań wspólnotowych", powtórzyła oraz rozwinęła bardzo wiele rozwiązań poprzedniej ustawy. Jednocześnie wprowadziła cały szereg nowych pomysłów, dzięki którym miało dojść do zażegnania kryzysu na linii Wspólnoty - Italia w przedmiocie implementacji prawa wspólnotowego ${ }^{9}$. Uchwalenie legge La Pergola wynikało przede wszystkim z konieczności znalezienia remedium na wciąż mało skuteczną i powolną implementację dyrektyw wspólnotowych, a także z faktu uchwalenia w 1986 r. Jednolitego Aktu Europejskiego ${ }^{10}$. Ów dokument zakładał osiągnięcie do roku 1992 ambitnego celu w postaci stworzenia wewnętrznego rynku wspólnotowego (w oparciu m.in. o zasady swobodnego

7 PITINO A. (2005), Verso una nuova..., p. 21; polskie nazewnictwo faz ascendente i discendente $\mathrm{w}$ tłumaczeniu własnym Autora.

8 Ustawa nr 86, „Gazzetta Ufficiale della Repubblica”, nr 58, 10.03.1989.

9 PITINO A. (2005), Verso una nuova..., p. 25.

10 CARTABIA M., WEILER J.H.H. (2000), L'Italia in Europa. Profili istituzionali e costituzionali, Bologna, p. 26. 
przepływu towarów i usług), do czego była konieczna odpowiednia reorganizacja rynków wewnętrznych oraz systemów normatywnych państw członkowskich Wspólnot. Konsekwencją tego było nałożenie na kraje obowiązku transpozycji szeregu dyrektyw, co w przypadku już znacznie opóźniających się i mało efektywnych Włoch musiało oznaczać konieczność podjęcia przez ten kraj niezwłocznych działań.

Obok powyższych czynników, które można nazwać czynnikami ,zewnętrznymi”, istniały też inne, o charakterze ,wewnętrznym”, do których należy zaliczyć: konieczność większego zaangażowania parlamentu w procesy tworzenia prawa na poziomie Wspólnot oraz na poziomie dostosowywania porządku normatywnego Włoch do wymagań Wspólnot, jak również reorganizacja normatywna w samym kraju, spowodowana wprowadzaniem do porządku wewnętrznego źródeł prawa pochodzenia zewnętrznego ${ }^{11}$. Odnośnie większego zaangażowania parlamentu nowa regulacja przewidywała jego aktywniejszy udział w stosunku do praktyki dotychczasowej, zarówno w fazie tzw. kreacji, jak i wdrażania prawa wspólnotowego. Warto podkreślić, iż w tej materii „La Pergola” wpisywała się doskonale w powstały na początku lat 90. ogólnoeuropejski trend, mający za zadanie zmniejszenie tzw. deficytu demokracji w procesie decyzyjno-normatywnym Wspólnot Europejskich i zwiększenie roli parlamentów narodowych ${ }^{12}$.

Najistotniejszym novum ustawy nr 86 było jednak skonstruowanie instrumentu „ustawy wspólnotowej” (legge comunitaria), który miał na celu dokonywanie corocznej, zbiorczej implementacji prawa unijnego do porządku krajowego oraz dzięki swej szczególnej systematyce, miał dopomóc w opanowaniu swoistego chaosu normatywnego panującego wówczas w Italii. Konieczność przestrzegania i wdrażania prawa unijnego powodowała bowiem przez lata niepewność co do tego, jaki organ i przy użyciu jakich metod powinien adaptować normy europejskie. W konsekwencji dochodziło do multiplikowania się krajowych ośrodków normatywnych oraz aktów mających wdrażać unijne przepisy ${ }^{13}$.

11 Ibidem, s. 152.

12 Przejawem uaktywnienia włoskiego parlamentu miało być m.in. większe doinformowanie tego organu ze strony rządu odnośnie prowadzenia włoskiej polityki wspólnotowej, a także bezpośredni, fizyczny udział izb przedstawicielskich w procesie corocznego uchwalania ,ustawy wspólnotowej"; ibidem.

13 Ibidem, s. 153. 
Obowiązująca aktualnie ustawa nr 11 z 2005 r. ${ }^{14}$, tzw. „ustawa Buttiglione”, kontynuuje w przeważającej mierze tradycje „La Pergoli”, choć oczywiście wprowadza także szereg nowych rozwiązań. Przyczyny uchwalenia nowej ustawy, regulującej kwestie związane z członkostwem Włoch w Unii Europejskiej, były analogiczne jak przy uchwalaniu jej poprzedniczek, z jednym zastrzeżeniem. Mianowicie legge Buttiglione miała uwzględnić niezwykle istotną reformę całego V Tytułu Konstytucji z 2001 r., która dokonała wiele kluczowych zmian w zakresie podziału kompetencji pomiędzy państwo a regiony włoskie. W obszarze relacji Włochy - Unia Europejska nowy art. 117 Konstytucji przewiduje, iż państwo posiada wyłączne kompetencje legislacyjne w zakresie stosunków z Unią Europejską (ust. 2), podczas gdy regiony mają prawo do utrzymywania tych stosunków w obrębie kompetencji konkurencyjnych (ust. 3) i w zakresie kompetencji im przyznanych uczestniczą $\mathrm{w}$ procesie formowania oraz wdrażania aktów wspólnotowych, działając w tej materii na podstawie ustawy państwowej (ust. 5) ${ }^{15}$. Zatem dzisiaj nie tylko państwo włoskie, czy konkretniej rząd i parlament, uczestniczą w implementacji prawa Unii, lecz także regiony, które dokonują tego w obrębie swych konstytucyjnych kompetencji. „La Pergola” była w tym kontekście zdecydowanie niewystarczająca ${ }^{16}$. Nowy stan faktyczny wymagał wydania stosownych ustaw państwowych w celu zapewnienia wykonania postanowień ustawy zasadniczej. Pierwszą z nich była ustawa nr 131 z 2003 r., tzw. „ustawa La Loggia"17, regulująca w przeważającej mierze fazę kreacji prawa unijnego (fase ascendente), kolejną natomiast omawiana „ustawa Buttiglione”.

To, co najistotniejsze dla omawianej tutaj kwestii, to fakt, iż ustawa nr 11 z 2005 r. utrzymała instytucję tzw. ustawy wspólnotowej, regulując szczegółowo jej treść i procedurę uchwalania, wskazując tym samym na główne sposoby implementacji prawa unijnego oraz organy $\mathrm{w}$ te procesy zaangażowane.

14 „Gazzetta Ufficiale della Repubblica”, nr 37, 15.02.2005, tekst ustawy dostępny na stronie internetowej Parlamentu Republiki Włoskiej: http://www.parlamento.it/parlam/leggi/050111.htm.

15 TIBERI G. (2005), La riforma della legge 'La Pergola', „Quaderni Costituzionali” nr 3, pp. $671 \mathrm{i}$ nast.

16 Przez okres kilku lat, od momentu wdrożenia reformy konstytucyjnej, do momentu uchwalenia ,ustawy Buttiglione” przepisy ustawy nr 86 były stosowane odpowiednio z uwzględnieniem zmian w Konstytucji.

17 „Gazzetta Ufficiale della Repubblica”, nr 132, 10.06.2003. 


\section{USTAWA WSPÓLNOTOWA}

Ustawa wspólnotowa, która stanowi współcześnie główne narzędzie, za pomocą którego Włochy wdrażają prawo unijne, uchwalana jest co roku przez parlament w nieco odmiennej procedurze, aniżeli ta przewidziana dla ustaw zwykłych. Przypomina ona w największym stopniu procedurę stanowienia ustawy budżetowej, przy czym, o ile obowiązek uchwalenia tej ostatniej w odpowiednim terminie jest wskazany wprost przez art. 81 Konstytucji, o tyle w przypadku ustaw implementujących prawo unijne, takiego obowiązku ustawa zasadnicza nie przewiduje ${ }^{18}$. Z tego powodu ustawodawcę nie spotka żadna wewnętrzna sankcja, gdyby danego roku nie uchwalił wspomnianej ustawy ${ }^{19}$. Choć oczywiście samo państwo musi liczyć się z ewentualnymi karami finansowymi nałożonymi przez Komisję Europejską. Przypadki uchwalania legge comuniataria z bardzo dużymi opóźnieniami zdarzały się już w przeszłości, zwłaszcza w latach 1994-199720.

Szczegółowo procedurę uchwalenia ,ustaw wspólnotowych” reguluje wspomniana wyżej ustawa nr 11 z 2005 r., a także regulaminy parlamentarne Izby Deputowanych i Senatu. Inicjatywę ustawodawczą, zgodnie z art. 8 ,ustawy Buttiglione", posiada jedynie rząd, a konkretniej - Prezes Rady Ministrów lub minister polityk europejskich, który działa przy współpracy z ministrem spraw zagranicznych i innymi zainteresowanymi ministrami. Projekt legge comunitaria wnoszony jest w terminie do 31 stycznia każdego roku i musi być do niego dołączone sprawozdanie rządu, w którym w szczególności: opisuje on stopień zgodności pomiędzy krajowym porządkiem normatywnym a prawem Unii Europejskiej, wskazując na wszelkie sytuacje naruszenia ze strony Włoch obowiązków europejskich i przedstawiając w tym kontekście stosowne orzeczenia Trybunału Sprawiedliwości; zamieszcza listę dyrektyw, które zostały implementowane lub mające być implementowane w drodze aktów administracyjnych; wskazuje na przyczyny niewdrożenia w terminie określonych dyrektyw; sporządza listę dyrektyw już implementowanych w drodze rozporządzeń; sporządza listę aktów normatywnych, uwzględniając $w$ niej także roczne regionalne ustawy implementacyjne, za pomocą których regiony oraz prowincje autonomiczne Trento i Bolzano dokonały wdrożenia dyrektyw odpowiednio w zakresie ich konstytucyjnych kompetencji.

18 GIANNITI L., LUPO N. (2008), Corso di diritto parlamentare, Bologna, pp. 233-235.

19 CARTABIA M., WEILER J.H.H. (2000), L'Italia in Europa..., p. 154.

20 BARONCELLI S. (2008), La partecipazione dell'Italia alla governance dell'Unione europea nella prospettiva del Trattato di Lisbona. Un'analisi sulle fonti del diritto nell'ottica della fase ascendente e discendente, Torino, p. 274. 
Analizując przepisy regulaminów parlamentarnych, należy stwierdzić, iż uchwalenie legge comunitaria przebiega według schematu właściwego dla procedury zwyczajnej (procedimento ordinario) uchwalania ustaw, choć zawiera pewne właściwe dla siebie elementy. Postępowanie ustawodawcze w Izbie Deputowanych reguluje art. 126 - ter regulaminu Izby, a w przypadku Senatu art. 144 - bis regulaminu Senatu. Postępowanie w drugiej izbie jest w zasadzie analogiczne, dlatego nie ma potrzeby poświęcać mu specjalnie odrębnej uwagi.

Procedura uchwalania ustaw rozpoczyna się od prac w komisjach - w Komisji Polityk Unii Europejskiej (La Commissione politiche dell'Unione europea) oraz w innych komisjach właściwych ze względu na zakres rozpatrywanych spraw. Generalnie można zatem określić, iż tryb przygotowawczy postępowania ustawodawczego odbywa się na posiedzeniu sprawozdawczym (in sede referente) w Komisji Polityk Unii Europejskiej, natomiast analiza poszczególnych części projektu ustawy wspólnotowej (l'esame delle parti) jest wykonywana przez odpowiednie komisje.

W postępowaniu przygotowawczym, jak i później w trakcie fazy stanowiącej postępowania ustawodawczego, przedmiotem prac komisji oraz izb parlamentarnych jest nie tylko projekt ustawy wspólnotowej, ale także sprawozdanie rządu dołączane do projektu. O ile w fazie przygotowawczej oba dokumenty są rozpatrywane łącznie, o tyle potem każdy z nich jest przedmiotem różnych postępowań - jeden, postępowania o charakterze ustawodawczym, drugi - postępowania o charakterze kontrolnym ${ }^{21}$.

Na początku prac w Izbie Deputowanych projekt trafia zatem do odpowiednich komisji. Jak stanowi art. 126 - ter ust. 2, komisje rozpatrujące poszczególne części projektu ustawy wspólnotowej mają 15 dni na zakończenie wszystkich czynności. Kończą postępowanie uchwaleniem sprawozdania (relazione) i wyznaczeniem sprawozdawcy, który może uczestniczyć w następnej fazie postępowania z projektem ustawy, tj. fazie odbywającej się w Komisji Polityk Unii Europejskiej (w Senacie, co do zasady sprawozdawca pomniejszej komisji sektorowej jest jednocześnie członkiem wspomnianej Komisji ${ }^{22}$ ). Jeżeli w pracy commisione di settore powstały jakieś sprawozdania mniejszości, muszą być one przekazane

21 Zob. Legge comunitaria 2008, A.C. 2320, Schede di lettura, n. 129, Servizio Studi-Dipartimento Affari Comunitari, Camera dei deputati, XVI legislatura, Documentazione per l'esame di Progetti di legge; dokument jest analizą projektu ustawy wspólnotowej za 2008 rok, ustawa 7 luglio 2009, nr 88, opublikowana w „Gazzetta Ufficiale della Repubblica”, nr 161, 14.07.2009 tekst ustawy jest dostępny na stronie: http://nuovo.camera.it/465 ?area=3\&tema=88\&Legge+comunitaria+2008; por. część pt.: La procedura di esame della legge comunitaria.

22 GIANNITI L., LUPO N. (2008), Corso di diritto..., p. 233. 
dalej również w terminie 15 dni i także w tym wypadku możliwe jest wyznaczenie jednego sprawozdawcy dla każdej mniejszości, który będzie mógł uczestniczyć w posiedzeniach Komisji Polityk Unii Europejskiej. W tym samym czasie komisje analizują także rządowe sprawozdanie dołączone do projektu, które jest następnie przedmiotem ich oceny (parere).

Po upływie 15 dni prace nad projektem ustawy wspólnotowej przenoszą się do Komisji Polityk Unii Europejskiej, która ma z kolei 30 dni na zakończenie tych prac i na uchwalenie dwóch sprawozdań - jednego, z projektu ustawy i drugiego, $\mathrm{z}$ analizy przedstawionej przez rząd. Oba dokumenty trafiają następnie wraz z dokumentami pozostałych komisji pod obrady plenarne. W praktyce przyjęło się, iż wskazany trzydziestodniowy termin ma charakter obowiązkowy (termine ordinatorio $)^{23}$.

Poprawki do projektu ustawy wspólnotowej są przedmiotem głosowania już na etapie prac właściwych komisji i następnie zostają przekazane do Komisji Polityk Unii Europejskiej wraz ze sprawozdaniami sporządzanymi przez komisje. Poprawki będą uważane za przyjęte, o ile, jak stanowi art. 126 - ter ust. 5, Komisja nie uzna, iż są sprzeczne z prawem wspólnotowym lub ze względu na tzw. generalne wymogi koordynacyjne (inne wymogi techniczne). Co ważne, wspomniana Komisja oraz już później deputowani i senatorowie nie mogą wprowadzać poprawek nie związanych z właściwym przedmiotem ustawy wspólnotowej. Co do zasady poprawki, które dotyczą kwestii merytorycznych projektu, są przekazywane do rozpatrzenia odpowiednim komisjom sektorowym, a Komisji Polityk Unii Europejskiej przedkładane są poprawki dotyczące kwestii porządkowych i organizacyjnych. Jeżeli Komisji zostaną przedstawione bezpośrednio poprawki dotyczące kwestii merytorycznych, to i tak muszą zostać zaopiniowane przez właściwe komisje sektorowe ${ }^{24}$.

Następnym etapem postępowania ustawodawczego w przedmiocie legge comunitaria, analogicznie do stanowienia ustaw w trybie procedury zwyczajnej, jest dyskusja generalna na forum Izby Deputowanych i odpowiednio Senatu oraz głosowanie nad projektem ustawy. W pierwszej kolejności pod głosowanie poddawane są poszczególne artykuły ustawy wspólnotowej, a następnie jej tekst w całości. Jednocześnie z parlamentarnymi pracami nad ustawą rozpatrywane jest sprawozdanie rządu. Stąd w praktyce wykształciło się pojęcie sessione comunitaria, czyli sesji wspólnotowej, jako zbiorcze określenie wszystkich czynności

\footnotetext{
23 Ibidem, p. 234.

${ }^{24}$ Ibidem.
} 
odbywających się odpowiednio w każdej z izb, nakierowanych na uchwalenie ustawy wspólnotowej i analizę powiązanych z nią dokumentów.

O ile termin sporządzenia projektu legge comunitaria jest wyraźnie określony w ustawie nr 11 z 2005 r. i jest nim dzień 31 stycznia każdego roku, o tyle odnośnie do uchwalenia ustawy przez parlament brak jest analogicznego przepisu. Nie przewiduje go również żaden z regulaminów izb. Taki stan rzeczy może być jedną z przyczyn wydłużania się postępowania legislacyjnego w parlamencie. Czasami zdarza się, iż procedura ustawodawcza przekracza rok kalendarzowy, w którym powinna być uchwalona legge.

Wydłużenie postępowania w izbach może być także spowodowane faktem, iż ustawa wspólnotowa, jak każda inna ustawa parlamentarna, musi być uchwalona w jednakowym brzmieniu zarówno przez Izbę Deputowanych jak i przez Senat. W praktyce możemy mieć do czynienia z sytuacją, w której jej tekst przez dłuższy czas „wędruje” pomiędzy izbami, aż do chwili osiągnięcia wymaganego konsensusu.

Ustawa wspólnotowa uchwalona w identycznej wersji musi być następnie promulgowana oraz ogłoszona. Promulgacji dokonuje Prezydent Włoch, natomiast tekst ustawy jest ogłaszany w Gazzetta Ufficiale della Repubblica Italiana ${ }^{25}$.

„Treść ustawy wspólnotowej określa art. 9 ustawy nr 11 z 2005 r. i składają się na nią: dyspozycje modyfikujące lub uchylające obowiązujące normy państwowe, które są sprzeczne z aktami wspólnotowymi bądź będące przedmiotem postępowania w sprawie naruszenia prawa wspólnotowego; dyspozycje mające na celu wdrożenie, także za pomocą delegacji ustawowej na rzecz rządu, każdego wspólnotowego aktu normatywnego oraz aktu Unii Europejskiej, który zobowiązuje Włochy do podjęcia stosownych działań wdrażających oraz decyzji ramowych i wszystkich innych decyzji wydawanych na płaszczyźnie współpracy policyjnej i sądowej w sprawach karnych (o których mowa w art. 34 Traktatu o Unii Europejskiej); dyspozycje upoważniające rząd do implementacji dyrektyw za pomocą rozporządzeń i aktów administracyjnych; dyspozycje skierowane na wykonanie traktatów międzynarodowych zawartych przez Unię Europejską w obrębie jej kompetencji zewnętrznych; dyspozycje tworzące podstawowe wytyczne, w oparciu o które regiony i prowincje autonomiczne dokonują implementacji aktów wspólnotowych w obrębie swych legislacyjnych kompetencji konkurencyjnych (o czym art. 117 ust. 3 Konstytucji); dyspozycje na rzecz rządu do wydawania

25 Więcej na temat procedury uchwalania ustaw we Włoszech WITKOWSKI Z. (2004), Ustrój konstytucyjny wspótczesnych Włoch $w$ aktualnej fazie jego przemian 1989-2004, Toruń, pp. 187 i nast. 
dekretów z mocą ustawy w obrębie kompetencji ustawodawczych regionów w sytuacji nałożenia kar finansowych z powodu naruszeniem prawa Unii; dyspozycje wydawane $\mathrm{w}$ związku z wykonywaniem władzy zastępczej państwa w oparciu o art. 117 ust. 5 Konstytucji”.

W nawiązaniu do powyższych unormowań „ustawy Buttiglione” wyróżnia się w literaturze przedmiotu cztery zasadnicze sposoby implementacji norm europejskich do włoskiego porządku krajowego: implementację za pomocą dekretów z mocą ustawy (decreto legislativo), implementację bezpośrednią, implementację przy użyciu rozporządzeń i innych aktów administracyjnych oraz implementację z zastosowaniem rozporządzeń tymczasowych z mocą ustawy (decreto - legge) i w trybie pilnym ${ }^{26}$. Do tych czterech sposobów należy także dodać metodę przewidzianą w art. 15 ,ustawy Buttiglione”, polegającą na wdrażaniu prawa unijnego w drodze aktów normatywnych regionów włoskich, a także prowincji autonomicznych.

\section{UDZIAŁ REGIONÓW WŁOSKICH W PROCESACH IMPLEMENTACYJNYCH}

Od momentu reformy konstytucyjnej z 2001 r., a także wejścia w życie realizujących jej postanowienia ustaw wykonawczych, regiony włoskie posiadają realny wpływ na procesy normatywne związane z członkostwem Italii w Unii Europejskiej, w tym na kwestie dotyczące implementacji prawa Unii. Ten wpływ przejawia się w praktyce w działalności prawotwórczej regionów odpowiednio w obrębie ich zakresu uprawnień legislacyjnych. Wszędzie tam zatem, gdzie regiony są uprawnione (czy w niektórych przypadkach wręcz zobligowane) do działania jako „implementator”, uchwalają stosowne ustawy regionalne (leggi regionali). Nowością w tym obszarze oraz jednocześnie ciekawym rozwiązaniem prawnym, które przewiduje legge Buttiglione, jest instrument normatywny zwany regionalną ustawą wspólnotową (legge comunitaria regionale). Wprawdzie ustawa nie posługuje się konkretnie takim właśnie terminem, to jednak odnosi się wyraźnie do omawianej instytucji, określając ją mianem ,rocznej ustawy wdrażającej" (art. 8 ust. 5 pkt e ustawy nr 11). Ponieważ jest ona de facto regionalnym odbiciem ustawy wspólnotowej, stąd w powszechnym użyciu przejmuje także jej nazwę.

${ }^{26}$ W ten sposób BARONCELLI S. (2008), La partecipazione dell'Italia ..., pp. 251-262. 
Legge comunitaria regionale jest to akt normatywny uchwalany co roku $\mathrm{w}$ formie ustawy przez właściwe organy regionu, który ma na celu implementację, odpowiednio w obrębie kompetencji regionalnych, aktów normatywnych Unii Europejskiej, a także urzeczywistnienie orzeczeń Trybunału Sprawiedliwości ${ }^{27}$. Jak widać zatem, ustawodawca państwowy uznał, iż regiony mogą korzystać z analogicznego, do tego państwowego, instrumentu implementacji prawa Unii. Sposób natomiast, w jaki regiony będą korzystać z ustawy wspólnotowej, czyli innymi słowy, uregulowanie tej instytucji, ustawodawca państwowy pozostawił do decyzji regionom. Tym sposobem wiele regionów uchwaliło ustawy organiczne dotyczące ich udziału w unijnych procesach normatywnych ${ }^{28}$. W szczególności ustawy te regulują dwa podstawowe zagadnienia: po pierwsze, materie związane z ich uczestnictwem w tworzeniu normatywnych aktów wspólnotowych, a w szczególności z udziałem w tym procesie giunty regionalnej (Giunta regionale), czyli de facto zarządu oraz rady regionalnej (Consiglio regionale) i kwestie związane z udziałem wszystkich innych organów regionalnych w formowaniu ogólnopaństwowej pozycji odnośnie projektów aktów wspólnotowych oraz dokumentów konsultacyjnych, takich jak zielone i białe księgi czy komunikaty; po drugie, materie związane z implementacją (zasadniczo za pomocą regionalnej ustawy wspólnotowej) unijnych aktów normatywnych oraz postanowień zawartych w orzeczeniach Trybunału Sprawiedliwości.

Generalne dyspozycje odnośnie relacji pomiędzy regionami a Unią Europejską są zawarte także we wszystkich nowych statutach regionów zwyczajnych, które to statuty uległy odpowiednim zmianom w następstwie wejścia w życie

27 Oprac. na podst. Legge comunitaria 2008, A.C. 2320, Schede di lettura, część pt.: Le leggi comunitarie regionali.

${ }^{28}$ Ustawy dotyczące udziału regionów w procesach dotyczących członkostwa Włoch w Unii Europejskiej-w szczególności udziału w fase ascendente i discendente- uchwaliły następujące regiony: Friuli-Wenecja Julijska (1.r. nr 10/2004 „Bollettino Ufficiale della Regione Friuli Venezia Giulia”, nr 14, 07.04.2004 oraz 1.r. nr 17/2007 art. 17 i 18 „Bollettino Ufficiale della Regione Friuli Venezia Giulia”, nr 26, 27.06.2007), Valle d'Aosta (1.r. nr 8/2006 „Bollettino Ufficiale della Regione Valle d'Aosta”, nr 14, 04.04.2006), Marche (1.r. nr 14/2006 „Bollettino Ufficiale della Regione Marche”, nr 99, 12.10.2006), Kalabria (1.r. nr 3/2007 „Bollettino Ufficiale della Regione Calabria”, nr 24, 12.01.2007), Umbria (1.r. nr 23/2007 art. 29-35 „Bollettino Ufficiale della Regione Umbria”, nr 32, 18.07.2007), Emilia-Romania (1.r. nr 16/2008 „Bollettino Ufficiale della Regione Emilia-Romagna”, nr 131, 28.07.2008), Kampania (1.r. nr 18/2008 „Bollettino Ufficiale della Regione Campania”, nr 51, 15.12.2008), Toskania (1.r. 26/2009 „Bollettino Ufficiale della Regione Toscana”, nr 18, 27.05.2009) oraz Molise (1.r. nr 4/2011 „Bollettino Ufficiale della Regione Molise", nr 4, 16.02. 2011); por. powyżej cytowany dokument, a także P. Bilancia, F.G. Pizzetti, Testi e progetti.., pp. 169 i nast. 
reformy konstytucyjnej z $2001 \mathrm{r}$. W przeważającym zakresie statuty te odsyłają bezpośrednio do ustaw regionalnych regulujących sprawy unijne, choć niektóre $\mathrm{z}$ nich zawierają same w sobie pewne specyficzne unormowania ${ }^{29}$.

W związku z faktem, że każdy region we własnym zakresie reguluje materie związane z uczestnictwem w procesie implementacji prawa Unii, w tym dotyczące interesującej nas tutaj regionalnej ustawy wspólnotowej, nie ma jednej, identycznej procedury uchwalania wspólnej dla każdego regionu. Pamiętajmy też, że nie wszystkie w ogóle sięgają po ten instrument. Te jednak, które się na to decydują, postępują bardzo podobnie, według pewnych wspólnych wyznaczników.

Projekt regionalnej ustawy wspólnotowej jest przedstawiany przez giuntę radzie we właściwym terminie, który różnicuje się w zależności od regionu (dla przykładu - do 31 marca projekt musi być przedstawiony we Friuli-Wenecji Julijskiej oraz w Valle d'Aosta, a do 1 lipca w Molise). Następnie projekt trafia pod obrady rady, która analizuje go w trakcie specjalnej sesji wspólnotowej (sessione comunitaria). Niekiedy do projektu dołączany jest raport dotyczący stanu realizacji polityk wspólnotowych w regionie (tak np. Kalabria, Marche, Molise). Regiony Umbria i Molise przewidują termin, przed upływem którego musi zostać uchwalona ustawa wspólnotowa - w Umbrii projekt ma być przedstawiony do 25 czerwca, a uchwalony do 25 stycznia każdego roku, w Molise natomiast projekt zostaje uchwalony do końca roku kalendarzowego, którego dotyczy ustawa wspólnotowa.

W swej treści każda regionalna ustawa wspólnotowa musi zawierać następujące elementy: dyspozycje modyfikujące lub uchylające normy prawne sprzeczne z prawem wspólnotowym, dyspozycje urzeczywistniające (wprowadzające w życie) postanowienia aktów wspólnotowych i orzeczeń Europejskiego Trybunału Sprawiedliwości, dyspozycje upoważniające giuntę do implementowania dyrektyw za pomocą rozporządzeń i innych aktów administracyjnych. Jak widać zatem, treść ustaw regionalnych kształtuje się w analogii do ustaw państwowych. Także analogicznie do uregulowań państwowych normy regionalne przewidują, iż do projektu ustawy giunta regionalna musi dołączyć sprawozdanie o stopniu zgodności ustawodawstwa regionalnego ze wspólnotowym wraz ze wskazaniem na ewentualne przypadki naruszenia prawa wspólnotowego przez regiony, a obciążające tym samym państwo włoskie.

${ }^{29}$ Por. Legge comunitaria 2008, A.C. 2320, Schede di lettura, część pt.: Le leggi comunitarie regionali. 
Generalnie rzecz ujmując, można powiedzieć, iż to, co różni w zasadniczym stopniu wszystkie procedury uchwalania regionalnych ustaw wspólnotowych (oprócz terminów oczywiście, co jednak jest kwestią drugorzędną), to stopień zaangażowania $\mathrm{w}$ ten proces poszczególnych organów regionalnych, w tym w szczególności giunty i rady oraz stopień przyznanych im kompetencji ${ }^{30}$.

Regiony, które do dnia dzisiejszego skorzystały z tego instrumentu, jakim jest regionalna ustawa wspólnotowa, to: Friuli-Wenecja Julijska, która uchwala tę ustawę co roku począwszy od 2004 r.; Valle d'Aosta, która po raz pierwszy skorzystała z tego instrumentu w 2007 r. oraz Marche i Kampania, które skorzystały z ustawy po raz pierwszy w 2008 r. Jak widać zatem, w praktyce instrument ten jest stosowany nadal w bardzo niewielkim zakresie.

\section{REFORMA W OBSZARZE IMPLEMENTACJI PRAWA UNII EUROPEJSKIEJ WE WŁOSZECH W ZWIĄZKU Z WEJŚCIEM W ŻYCIE TRAKTATU Z LIZBONY}

Traktat z Lizbony dokonał wiele ważnych modyfikacji w obrębie całej struktury Unii Europejskiej. Na mocy tego dokumentu, by wskazać na najbardziej ewidentne przykłady, został obalony dotychczasowy system opierający się na strukturze trzech filarów, a także przestał istnieć formalny podział na Unię oraz Wspólnoty Europejskie. Mając na względzie to, że dotychczasowy normatywny system wspólnotowy przestał istnieć, nieadekwatne stały się wszelkie odniesienia, zawarte we włoskich uregulowaniach wewnętrznych, do prawa wspólnotowego, aktów wspólnotowych czy nawet krajowej ustawy wspólnotowej. Wraz z likwidacją filarów utworzono nową systematykę aktów normatywnych, a jej uwzględnienie stało się konieczne w obrębie wewnętrznych przepisów dotyczących ich implementacji.

Traktat dokonał także szeregu zmian o charakterze proceduralnym w zakresie tworzenia prawa na poziomie organów unijnych. W większym stopniu niż dotychczas zostały zaangażowane w tę fazę parlamenty krajowe, co przejawia się chociażby w przyznanym im uprawnieniu do kontroli należytego posługiwania się przez Unię zasadą subsydiarności. Jednocześnie państwa członkowskie zostały zmuszone do szybszej i skuteczniejszej implementacji przepisów europejskich - skrócono terminy odpowiedzialności za brak wdrożenia dyrektyw oraz zadość-

30 Zob. szerzej ibidem. 
uczynienia decyzjom Komisji nakładającym kary finansowe. Zmiany te nie mogły pozostać bez reakcji również ze strony ustawodawcy włoskiego.

Oprócz konieczności dostosowania się do nowych prawno-instytucjonalnych zmian „w sercu" samej Unii Europejskiej reformę krajową przyspieszyły także czynniki o charakterze wewnętrznym. Podobnie jak przy uchwalaniu ,ustawy Buttiglione", tak i obecnie należałoby zreformować szereg rozwiązań o charakterze czysto wewnętrznym - począwszy od poprawienia współpracy pomiędzy podmiotami zaangażowanymi w procesy kreacji i wdrażania norm unijnych, a na udoskonaleniu samego instrumentu ustawy wspólnotowej skończywszy. Jak się okazuje bowiem, wciąż jest jeszcze wiele do zrobienia w obszarze implementacji prawa unijnego. Statystyki pokazują, że Italia w okresie po uchwaleniu ustawy nr 11 z 2005 r. zmniejszyła swój deficyt w obrębie implementacji dyrektyw z $3,8 \%$ do $1,4 \%^{31}$. Niemniej jednak, kraj ten wciąż pozostaje w grupie siedmiu państw, które nie osiągnęły ustalonego przez Komisję Europejską w 2007 r. maksymalnego marginesu tolerancji wynoszącego $1 \%$ dla braku transpozycji tych aktów ${ }^{32}$. Zmniejszyła się też niemal o połowę liczba postępowań w związku z naruszeniem prawa unijnego, skierowanych przeciw państwu włoskiemu, lecz nadal ich ilość i dotkliwe skutki finansowe dla budżetu krajowego przemawiają za poprawianiem skuteczności wewnętrznych mechanizmów wdrażania prawa unijnego ${ }^{33}$.

Doświadczenie ostatnich lat pokazało, że dotychczasowe metody implementacji były niewystarczająco skuteczne w trzech zasadniczych obszarach ${ }^{34}$. Po pierwsze, parlament zbyt długo zatwierdzał roczne ustawy wspólnotowe, co w konsekwencji blokowało właściwą realizację zobowiązań unijnych. Przejawiało się to w szczególności w uniemożliwieniu sprawnej realizacji przez rząd delegacji zawartych w tych ustawach. Jeśli zauważymy, że dekrety z mocą ustawy

31 Dane przedstawione w rządowej Analisi tecnico-normativa dołączonej do projektu nowej ustawy regulującej kwestie związane z członkostwem Włoch w Unii Europejskiej (projekt Rady Ministrów nr 3866; tekst wraz z uzasadnieniem dostępne na stronie internetowej: http://www. astrid-online.it/Riforma-de/Atti-parla1/Schema-di-/AC-3866.pdf, p. 29.

32 Włochom towarzyszy Austria, Portugalia, Czechy, Polska, Luksemburg i Grecja; zob. pp. 30-31 Analisi tecnico-normativa.

33 Włochy znajdują się na trzecim miejscu, jeśli chodzi o ilość wszczętych przeciwko państwu postępowań, wyprzedzają je tylko Grecja i Portugalia. Według stanu na dzień 31 maja 2010 r. ich ilość wynosiła 132, z czego 80\% dotyczyła spraw wynikających z naruszenia prawa Unii a 20\% spraw w związku z brakiem implementacji dyrektyw. Kary pieniężne nakładane na państwo członkowskie nie stosujące się do decyzji wymierzających kary finansowe, wynoszą średnio 238.000 euro za jeden dzień zwłoki; por. dane p. 30 Analisi tecnico-normativa.

34 Ibidem. 
(decreti legislativi) stanowią od momentu uchwalenia pierwszej legge comunitaria, główny sposób implementacji dyrektyw, to nie dziwi, że w tych okolicznościach ich efektywność nie mogła być w pełni realizowana.

Po drugie, jeśli parlamentarne delegacje zawarte w ustawie wspólnotowej były już w praktyce realizowane przez rząd, to i tak bardzo często implementacja następowała dopiero po upływie czasu dla transpozycji dyrektywy. Nagminnie łamano przepis ustawy nr 11 obligujący do wydawania dekretów ustawowych w terminie przewidzianym dla wdrażania prawa unijnego oraz równie często ze sporymi opóźnieniami publikowano teksty aktów w Gazzetta Ufficiale.

Po trzecie, od lat notuje się duże opóźnienia w przedmiocie implementacji prawa Unii ze strony administracji publicznej, która w tych wszystkich przypadkach, w których nie jest niezbędne wydanie ustawy lub aktu normatywnego posiadającego jego moc, bierze udział w procesie wdrażania przepisów europejskich. Mowa tu w szczególności o mało wydajnym w praktyce użyciu przez kompetentne ministerstwa wszelkiego rodzaju dekretów ministerialnych, których włączenie $\mathrm{w}$ proces implementacji dyrektyw miało w założeniu usprawnić cały system.

Powyższe przyczyny skłoniły rząd włoski, a także parlamentarzystów do zainicjowania prac nad zmianą „ustawy Buttiglione”. Konieczność modyfikacji dotychczasowych unormowań krajowych w związku z wejściem w życie Traktatu z Lizbony zaczęła coraz powszechniej pojawiać się w publicznych debatach na przełomie 2009/2010 r. i de facto od tego momentu przygotowania do uchwalenia nowej ustawy nabrały przyspieszenia. W chwili obecnej (25 października 2012 r.) rozpoczęło się w Izbie Deputowanych drugie czytanie projektu zmieniającego legge Buttiglione ${ }^{35}$, w Senacie natomiast zakończył się etap pierwszego czytania ${ }^{36}$. Prace parlamentarne ograniczają się aktualnie do analizy kilku najważniejszych projektów, pośród których w szczególności należy wymienić projekt rządowy nr 3866, zaprezentowany 16 listopada 2010 r. w Izbie Reprezentantów m.in. przez

35 Zob. uwagi Przewodniczącego N. Lo Presti zawarte w jego sprawozdaniu przedstawionym dnia 23 listopada 2010 r. na forum Komitetu legislacyjnego (Comitato per la legislazione) pt. Gli strumenti di recepimento ed attuazione degli obblighi comunitari, dokumnet dostępny na stronie internetowej: http://www.astrid-online.it/Riforma-de/Atti-parla1/index.htm.

36 Por. informacje zawarte na stronie internetowej włoskiej Izby Deputowanych: http://nuovo. camera.it/126?action=submit\&leg=16\&pdl=2854-b\&stralcio=\&navette=\&cerca=cerca. Zob. także Disegni di legge AA. SS. nn. 2646 e 2254 Partecipazione dell'Italia alla formazione e all'attuazione della normativa e delle politiche dell'Unione europea, Schede di lettura, Servizio Studi del Senato, maggio 2011, n. 292. 
ministra spraw polityk europejskich A. Ronchiego oraz projekty deputowanych: R. Buttiglione, G. Stucchi, S. Gozi i M. Pescante ${ }^{37}$.

Na dzień dzisiejszy nie jest możliwe jednoznaczne ustalenie ostatecznej treści przyszłej ustawy, która regulowałaby kwestie związane z udziałem Włoch w procesie formacji i wdrażania norm oraz polityk Unii Europejskiej. Analizując jednak poszczególne projekty i kolejne ich modyfikacje należy uznać, iż w obszarze spraw związanych z implementacją prawa unijnego znajdą zastosowanie propozycje zawarte w rządowym projekcie nr 3866. Moje rozważania ograniczę zatem do przedstawienia nowatorskich rozwiązań wspomnianego projektu.

Najistotniejsze novum rządowej propozycji zmian jest postulat, by zamienić dotychczasową legge comunitaria na dwa akty normatywne, oba uchwalane jak dotychczas w trybie rocznym. Jednym z nich miałaby być ustawa delegacji europejskiej (legge di delegazione europea), a drugim ustawa europejska (legge europea). Pierwsza z nich powinna zawierać w swej treści jedynie delegacje ustawowe, jak również wszelkiego rodzaju upoważnienia do urzeczywistnienia norm unijnych w formie aktów administracyjnych, a jej projekt musiałby wpłynąć do parlamentu do 28 lutego danego roku. Kolejna, której projekt mógłby zostać wniesiony niezależnie od ustawy delegującej, zawierałaby postanowienia wprost dostosowujące porządek wewnętrzny do europejskiego, takie jak przepisy modyfikujące lub uchylające dyspozycje z nim sprzeczne, czy bezpośrednio implementujące jego normy.

Idea, by rozłożyć na dwie części materię dotychczasowej legge comunitaria, wypływa, jak zapewniają twórcy projektu $\mathrm{nr} 3866$, z potrzeby zapewnienia większej skuteczności wewnętrznym instrumentom implementacji ${ }^{38}$. Uproszczenie konstrukcji ustawy delegującej umożliwi, zgodnie z przewidywaniami rządu, jej sprawniejsze uchwalenie przez parlament, a potem skróci rządowy okres na wydanie stosownych przepisów. Praktyka pokazuje, że dyspozycjami, które zazwyczaj wydłużały prace w izbach, były dyspozycje modyfikujące lub uchylające unormowania krajowe, uchwalane w celu odciążenia lub uchronienia państwa od kar finansowych nakładanych przez Unię ${ }^{39}$. Stąd też pomysł, by wydzielić je do ustawy europejskiej.

37 Odpowiednio projekty deputowanych: C. 2854 Buttiglione (UdC) e altri, C. 2862 Stucchi (LNP) e altri, C. 2888 Gozi (PD) e altri i C. 3055 Pescante (PdL) e altri; dostępne w formie tekstu zunifikowanego dla potrzeb prac Komisji do spraw Unii Europejskiej na stronie internetowej: http:// www.astrid-online.it/Riforma-de/Atti-parla1/index.htm.

${ }^{38}$ Por. uzasadnienie rządowego projektu ustawy, p. 10.

39 Ibidem. 
Treść ustawy delegacji europejskiej oraz ustawy europejskiej jest określona $\mathrm{w}$ art. 20 projektu rządowego. Zgodnie z tym przepisem pierwsza z ustaw powinna zawierać: delegacje dla rządu w przedmiocie dokonania transpozycji dyrektyw oraz decyzji ramowych, dyspozycje upoważniające rząd do wdrażania dyrektyw w drodze rozporządzeń wykonawczych, delegacje do wdrożenia stosownych przepisów w związku z naruszeniem przez Włochy prawa Unii Europejskiej oraz do wdrożenia ewentualnych przepisów niebezpośrednio skutecznych zawartych w rozporządzeniach unijnych, dyspozycje związane z działalnością legislacyjną regionów włoskich, a w szczególności fundamentalne wytyczne, w oparciu o które regiony sprawują swoją władzę ustawodawczą zgodnie z art. 117 ust. 3 Konstytucji.

Ustawa europejska natomiast powinna zawierać: dyspozycje modyfikujące lub zmieniające obowiązujące przepisy krajowe sprzeczne z prawem unijnym, w tym takie przepisy, które stały się przedmiotem postępowania wszczętego przez Komisją Europejską w sprawie naruszenia prawa (procedura d'infrazione), dyspozycje niezbędne do wdrożenia bądź należytego zapewnienia aplikacji prawa Unii Europejskiej, a także do wykonania traktatów międzynarodowych zawartych przez Unię w ramach jej kompetencji zewnętrznych oraz dyspozycje wydawane W związku z wykonywaniem tzw. władzy zastępczej państwa zgodnie z art. 117 ust. 5 Konstytucji. Jak widać zatem, treść obu instrumentów implementacji miałaby być zasadniczo tożsama $\mathrm{z}$ dotychczas uchwalaną legge comunitaria.

Na podstawie analizy dyspozycji rządowego projektu należy także uznać, że nie uległy modyfikacji zasadnicze sposoby wdrażania norm europejskich, które wskazywałam powyżej. Pozostają nimi nadal: implementacja za pomocą dekretów z mocą ustawy (decreto legislativo), implementacja bezpośrednia, implementacja za pomocą rozporządzeń i innych aktów administracyjnych, implementacja z zastosowaniem rozporządzeń tymczasowych z mocą ustawy (decreto - legge) i w trybie pilnym oraz implementacja w drodze aktów normatywnych regionów włoskich, a także prowincji autonomicznych.

Uchwalanie ustaw europejskich będzie odbywało się najprawdopodobniej w procedurze analogicznej do tej, przewidzianej dla uchwalania ustaw wspólnotowych. W rządowej propozycji odnajdziemy zaledwie dwie warte odnotowania zmiany w tym obszarze. Projekt legge comunitaria wnoszony jest, zgodnie $\mathrm{z}$ aktualnymi unormowaniami, w terminie do 31 stycznia każdego roku. Natomiast projekt legge di delegazione europea powinien trafić do parlamentu w terminie do 28 lutego i ma być dodatkowo opatrzony w opinię Stałej Konferencji do Spraw Stosunków Pomiędzy Państwem, Regionami i Prowincjami Autonomicznymi Trento i Bolzano. Dla projektu legge europea, jak się wydaje, nie prze- 
widziano analogicznych wymagań ani co do terminu, ani co do konieczności uzyskania stosownej opinii.

Wśród komentarzy rządowej reformy systemu wdrażania prawa Unii można dziś usłyszeć opinie zarówno jej przychylne, jak i te bardziej powściągliwe. Najwięcej emocji wzbudza, jak można się łatwo domyślić, idea podwojenia instrumentu ustawy implementującej. Choć jest ona z założenia rozwiązaniem nakierowanym na poprawę efektywności całego procesu, gdyż skraca i usprawnia procedurę delegacji na rzecz rządu, ma też swoje słabe strony. Przede wszystkim, jak podkreślają niektórzy, na każde postępowanie legislacyjne składa się szereg bardzo skomplikowanych czynności mających na celu uchwalenie ustawy. W tak trudnej materii, jaką jest dostosowanie porządku krajowego do wymogów stawianych przez Unię Europejską, procedura parlamentarna, siłą rzeczy, komplikuje się jeszcze bardziej, a jej podwojenie na pewno niczego nie ułatwi ${ }^{40}$. Sessione comunitaria, zarówna ta odbywająca się w Izbie Deputowanych, jak i w Senacie, powinna być ograniczona bardzo precyzyjnymi terminami i do tego w głównej mierze należałoby zmierzać, reformując dotychczasowe rozwiązania włoskie. Dopiero wówczas moglibyśmy mieć realną nadzieję na usprawnienie systemu implementacji prawa europejskiego przez centralne organy państwa i w konsekwencji na terminową realizację zobowiązań wynikających z członkostwa w Unii Europejskiej.

Warto w tym miejscu wspomnieć o tym, że choć sama konieczność wprowadzenia reformy dotychczasowego systemu implementacji nie budzi wątpliwości, to można też usłyszeć głosy całkowicie negujące ideę posługiwania się instrumentem ustawy wspólnotowej, a zatem negujące dotychczasowe metody implementacji norm unijnych ${ }^{41}$. W jednym z projektów reformy legge Buttiglione pojawiła się bowiem propozycja, by w ogóle odejść od dotychczasowego systemu, zainicjowanego u schyłku lat 90. i porzucić koncepcję wdrażania prawa unijnego „,pod dyktando” zbiorczych ustaw wspólnotowych. Alternatywą byłaby idea korzystania w przeważającej mierze z tzw. zwyczajnej legislacji parlamentarnej, a zatem także częściowe osłabienie zjawiska ustawodawstwa delegowanego. Jak piszą w uzasadnieniu twórcy powyższej koncepcji: „,ustawa wspólnotowa ma dziś hybrydowy profil polityczno-administracyjny, który zmniejsza jej demokratyczny

${ }^{40} \mathrm{~W}$ ten sposób prof. Vincenzo Lippolis w swoim wystąpieniu na seminarium pt. Parlamenti nazionali e processi decisionali dell'Unione europea, które odbyło się w dniach 2-3 lutego 2011 na Università degli Studi di Milano, Dipartimento di Scienze Politiche.

${ }^{41}$ Zob. projekt ustawy nr 2254 popierany m.in. przez senator F.M. Marinaro (PD), zaprezentowany w Senacie 24 czerwca $2010 \mathrm{r}$. 
status i umieszcza ją na marginesach wewnętrznej debaty"42. Utrwalając w pewnym sensie jej wizerunek jako systemu ,awaryjnego uruchamiania”, doprowadza się to tego, że polityka europejska nadal jest postrzegana przez reprezentację polityczną i publiczną administrację jako coś całkiem zewnętrznego wobec polityki krajowej. Wpisując się w założenia najnowszej reformy Unii Europejskiej, która zakłada wzmocnienie polityczno-instytucjonalne w obszarze udziału państw członkowskich w fazie tworzenia prawa europejskiego, należy porzucić ustawę wspólnotową, jako powszechny instrument wdrażania i wzmocnić odpowiedzialność parlamentu krajowego w tej płaszczyźnie ${ }^{43}$. Tym sposobem zwykła ustawa parlamentarna powinna przejąć rolę głównego instrumentu implementacji.

\section{PODSUMOWANIE}

Implementacja prawa Unii Europejskiej we Włoszech „,angażuje” współcześnie cały krajowy system źródeł prawa - począwszy od ustaw parlamentarnych, a na aktach normatywnych autonomii lokalnych skończywszy. Wdrażanie przepisów unijnych do porządku wewnętrznego stanowi dziś ważny element szeroko rozumianej działalności prawotwórczej włoskich organów centralnych i regionalnych. Jak pokazują dane statystyczne, w latach 2006-2009 akty nakierowane na ten cel stanowiły prawie jedną trzecią wszystkich źródeł prawa pierwszego stopnia ${ }^{44}$.

Od 1989 r. głównym instrumentem implementacji jest tzw. ustawa wspólnotowa, uchwalana w trybie corocznym przez izby parlamentarne, lecz w praktyce jej dyspozycje ,delegują" zadania do regulacji innych aktów normatywnych, uprzywilejowując w szczególności źródła posiadające moc ustawy. Decreto legislativo jest tutaj aktem absolutnie dominującym. W wymiarze dotyczącym spraw stricte wewnętrznych dekrety są używane przede wszystkim przy okazji organicznych lub sektorowych reform w takich sprawach, jak np. organizacja administracji, zdrowie, ubezpieczenia społeczne, tworząc coś na kształt 'riserva di delega',

42 Zob. uwagi zawarte we wprowadzeniu do projektu ustawy wspólnotowej za 2010 r., dokument dostępny na stronie:http://www.astrid-online.it/Documenti/Leggi-comu/Disposizio4/Sen_Dossier_270_gen2011.pdf.

${ }^{43}$ Ibidem, p. 17.

44 Por. dane zawarte w sprawozdaniu pt. Gli strumenti di recepimento ed attuazione degli obblighi comunitari, op. cit. 
czyli wyłączności delegacji. Natomiast w tzw. sferze wspólnotowej decreto legge jest stosowany nawet dla drobnych korekt przepisów prawnych ${ }^{45}$.

Jak pokazuje praktyka, Włochy coraz lepiej radzą sobie w sferze implementacji prawa unijnego. Na bieżąco usprawniają wewnętrzne instrumenty prawne stosowane dla tych celów, choć istnieje wciąż wiele do zrobienia w tej materii, czego dowodem jest aktualnie trwająca debata w kraju oraz liczne projekty nowelizujące ustawę nr 11 z 2005 r., które wpłynęły do izb parlamentarnych. Czas pokaże, jaki kształt ostatecznie przyjmie nowa ustawa, regulująca kwestię członkostwa Italii w Unii Europejskiej. Analizując dokumenty będące przedmiotem prac parlamentu w chwili obecnej, należy jednak podkreślić, że zmierzają one wszystkie w kierunku podwojenia dotychczasowej ustawy wspólnotowej, a zatem można z dużą dozą prawdopodobieństwa uznać, iż Włochy będą posługiwać się W niedalekiej przyszłości dwoma instrumentami implementacji prawa unijnego - ustawą europejską i ustawą delegacji europejskiej. Wydaje się, że równie ważną, jak i obecnie, rolę w procesie wdrażania przepisów europejskich, będą pełniły nadal regiony włoskie. Tym samym może z czasem wzrośnie także powszechność użycia regionalnych ustaw wspólnotowych/europejskich.

\section{Summary}

\section{IMPLEMENTATION OF EUROPEAN UNION LAW IN ITALY IN THE CONTEXT OF CHANGES IMPOSED BY LISBON TREATY}

One of the principal duties of the Member States of the European Union is obligatory implementation of law proclaimed by this organization. However, EU leaves to Member States freedom in selecting the means and methods to implement European legal regulations. In this context, Italy is using an interesting legal instrument - a community act, which is passed by parliament every year in the form designed, except some minor differences, for common parliament acts. Community act, most importantly, empowers Italian government to issue decrees having the force of ordinary law. Today, this instrument is indeed the major mean of implementation of European regulations in Italy. After 2001 amendment to the Constitution, also Italian regions has been taking active part in the implementation processes, passing regional community acts in analogy to country community act.

Starting from 1st December 2009 the entry into force of the Lisbon Treaty enforced changes in Italian regulations regarding membership in European Union, in particular in

45 Ibidem. 
Buttiglione Act passed in 2005. One of the major changes in existing regulations regarding implementation of the EU law is the proposal to substitute community act with two instruments: European act and European delegation act. The latter is supposed to be passed faster and more effectively from community act, which according to the expectations should improve domestic implementation processes.

\section{Riassunto}

\section{IL RECEPIMENTO DEL DIRITTO DELL'UNIONE EUROPEA IN ITALIA NELLA PROSPETTIVA DI NUOVO TRATTATO DI LISBONA}

Uno degli obblighi più importanti che risale dal fatto di essere lo stato membro dell' $U$ nione Europea, è l'obbligo di adeguarsi alle normative europee. Sono i stati, in pratica, a decidere in che modo e con quali strumenti recepire gli atti europei. L'Italia è uno degli esempi più interessanti in questo campo, soprattutto per il fatto di usare la legge comunitaria, che ormai da anni aiuta di adeguarsi agli obblighi derivanti dall'appartenenza all'Unione. La legge comunitaria è approvata ogni anno dal parlamento e contiene, nella maggior parte, le deleghe al governo italiano di emanare gli atti con forza di legge necessari per il recepimento delle direttive. Oggi il tipico modo recepimento rimane proprio quella che passa attraverso la delega legislativa. Dalla modifica costituzionale dal 2001 sono anche le regioni italiane, che insieme con gli organi statali danno tempestiva attuazione agli obblighi europei.

L'entrata in vigore l' 1 dicembre 2009 del Trattato di Lisbona rende indispensabile un intervento legislativo di riforma della legge n. 11 del 2005 (legge Buttiglione). Una delle idee di gran rilievo che cambia lo status quo attuale, è la proposta di riformare lo strumento della legge comunitaria e, in realtà, di sostituirla alle due distinte leggi annuali: la legge europea e la legge di delegazione europea. Quest'ultima avrebbe dovuto di essere emanata in tempi più stretti per garantire al governo la migliore possibilita di disporre delle deleghe legislative necessarie per il recepimento degli atti europei.

Słowa klucze: implementacja prawa Unii Europejskiej, ustawa wspólnotowa, regionalna ustawa wspólnotowa, delegacja ustawowa, dekret z mocą ustawy. 